\title{
SCIDoC
}

\author{
International Journal of Dentistry and Oral Science (IJDOS) \\ ISSN: 2377-8075
}

\section{Effect Of Intracanal Analgesia To Control Interappointment Pain During Root Canal Treatment - A Literature Review}

Research Article

Nivedhitha ${ }^{1 *}$, Sneha $\mathrm{Pai}^{2}$

${ }^{1}$ Professor and Head, Department of Conservative Dentistry and Endodontics, Saveetha Dental College and Hospitals, Saveetha Institute of Medical and Technical Sciences, Saveetha University 162, Poonamallee High Road, Chennai 600077, Tamilnadu, India.

${ }^{2}$ Department of Conservative Dentistry \& Endodontics, Saveetha Dental College and Hospitals, Saveetha Institute of Medical and Technical Sciences, Saveetha University, Chennai, India.

\section{Abstract}

Endodontic treatment is often associated with pain in most of the patients and so pain management in endodontics has always been of concern to all the dentists. In anticipation of pain during root canal treatment, the patients' anxiety levels shoot up which makes the treatment procedure difficult, disrupts scheduling and creates discomfort to the dentists. Interappointment pain during root canal treatment has been believed to be caused by acute inflammation in the periapical area. Several agents have been used for the management of this pain and various routes of administration have been studied for the delivery of these agents to manage pain effectively. This review would discuss the pathophysiology of endodontic pain, the agents used and the routes of delivery of these agents for the management of interappointment pain during root canal treatment along with a novel technique of administering the drug locally at the site of action with minimum concentration for effective pain control.

Keywords: Analgesia; Interappointment Pain; Mefenamic Acid; Aceclofenac; Local Drug Delivery.

\section{Introduction}

The frequency of interappointment pain during root canal treatment and the patients' anxiety associated with it has created major concern among dentists regarding pain management. Also a positive correlation has been made between the preoperative apprehension and postoperative pain [1,2]. Several studies have been carried out to assess the most effective method of analgesia and anesthesia to make endodontic treatment pain free.

Pain during endodontic treatment can be classified in to three sub headings: pain occuring before the initiation of endodontic treatment, pain during endodontic treatment and pain that develops after the treatment. Post endodontic pain is experienced by $25-40 \%$ of the patients undergoing endodontic treatment and it comprises interappointment pain and post obturation pain [3-6]. Interappointment pain is caused due to acute inflammatory reaction in the apical periodontal ligament which could be due to over instrumentation, extrusion of debris or medicament beyond apex, injury to the vital nerve or pulp tissue or due to occlusal trauma [7-10]. This inter appointment pain can be managed by occlusal reduction, use of antibiotics, corticosteroids or analgesics [11].

Previously our team has a rich experience in working on various research projects across multiple disciplines [12-42] Now the growing trend in this area motivated us to pursue this project.

This review will highlight the causes and mechanisms of interappointment pain along with the treatment approaches for its management.

\section{*Corresponding Author:}

Nivedhitha,

Professor and Head, Department of Conservative Dentistry and Endodontics, Saveetha Dental College and Hospitals, Saveetha Institute of Medical and Technical Sciences, Saveetha University 162, Poonamallee High Road, Chennai 600077, Tamilnadu, India.

Tel: +919840912367

Email Id: nivedhitha@saveetha.com

Received: April 28, 202

Accepted: May 28, 202

Published: May 30, 2021

Citation: Nivedhitha, Sneha Pai. Effect Of Intracanal Analgesia To Control Interappointment Pain During Root Canal Treatment - A Literature Review. Int J Dentistry Oral Sci. 2021;08(05):2632-2636. doi: http://dx.doi.org/10.19070/2377-8075-21000515

Copyright: Nivedhitha 2021 . This is an open-access article distributed under the terms of the Creative Commons Attribution License, which permits unrestricted use, distribution and reproduction in any medium, provided the original author and source are credited. 


\section{Causes Of Interappointment Pain}

Interappointment pain is caused due to mechanical, chemical or microbial injuries to the pulpal or periapical tissues during root canal treatment $[43,44]$. It has been reported that the severity of inflammation is proportional to the magnitude of tissue damage [45].

Microbial injury has been proposed as one of the common causes of interappointment pain $[44,46]$. This can be proved by the fact that interappointment pain is reported to be significantly higher in teeth with periradicular pathosis in comparison to teeth with vital pulps and healthy periapical condition [47, 48]. Mechanical and chemical causes when added up with the microbial involvement, interappointment pain is aggravated.

\section{Microbial Causes}

Interappointment pain is a result of imbalance between host and bacteria during intracanal procedures. There are a few circumstances where micro organisms cause inter appointment pain and these are dependent of several factors which are interlinked.

Presence Of Pathogenic Bacteria: Presence of pathogenic bacteria would initiate the inflammatory process and these bacteria are believed to be those involved with primary root canal infections. Moreover, their virulent forms would exaggerate the inflammatory response [49].

The Microbial Load and Microbial Synergism: More the microbial load, more exaggerated inflammatory response would be triggered resulting in postoperative pain. Also, most of the endodontic pathogens would exhibit virulence when present in association with other species due to synergistic microbial interactions [50-54].

Host Resistance and Environmental Cues: Host resistance is a deciding factor whether the infection will continue or not. Individuals usually present with varying patterns of resistance to infections and those with a reduced ability to resist the infection will be prone to develop clinical symptoms of inflammation after endodontic procedures, especially in infected root canals [55, 56]. A virulent prototype of an organism does not always express virulence and this virulence is activated only in the presence of certain environmental factors [57]. If the environment of the root canal is altered by intracanal procedures, it might provide optimum conditions for the microbial virulence which in turn aggravates interappointment pain.

Apical Extrusion Of Debris: This is one of the commonly cited reasons for the development of postoperative pain $[44,58,59]$. During chemo mechanical preparation, micro organisms are extruded in to the periapical space which initiates an inflammatory response, the severity of which depends on the load of organisms pushed into the periapex. This inflammation which tries to establish the equilibrium would result in interappointment pain.

Incomplete Instrumentation: Incomplete chemomechanical preparation would disrupt the balance with in the microbial community by eliminating some inhibitory species and leaving behind others which when overgrows would initiate inflammatory response resulting in inter appointment/post endodontic pain [60].

Secondary Intraradicular Infections: These infections are caused by microorganisms that weren't a part of root canal infection but have gained entry into the root canal during the treatment. This could mainly be due to break in isolation during the treatment [61]. If the microorganisms causing secondary infection happen to be virulent, they multiply and initiate inflammatory response in the periapex causing post treatment pain.

\section{Non Microbial Causes}

Non microbial causes can also result in periapical inflammation and pain These are usually iatrogenic in origin. Non microbial causes consist of physical and chemical factors which on interaction with the periapical tissues, give rise to interappointment pain. The severity of the pain is controlled by the degree of damage to the periapical tissues, intensity of injury and the inflammatory response.

Mechanical Factors: Over instrumentation and overfilled root canals are common examples for mechanical factors causing interappointment pain. Over instrumentation with large sized instruments would not only damage the periapical tissues but also extrude the microorganisms into the periapical area resulting in inflammation and pain. Over extended filling materials would compress the periapical tissues resulting in pain.

Chemical factors: Intracanal irrigants and medicaments are toxic and are formulated for use within the root canals. Extrusion of these materials in the periradicular space would incite an inflammatory reaction resulting in post endodontic pain [62-66]. Over extended filling materials have also been found to chemically irritate the periapical tissues leading to pain.

\section{Pathophysiology Of Interappointment Pain}

Interappointment pain is as a result of acute inflammation in the periapical area. When the periapical tissue is injured, various chemical substances are activated which would initiate the inflammatory pathway resulting in vasodilation, improved vascular permeability and chemotaxis of inflammatory cells. The chemical mediators released from the inflammatory pathway include prostaglandins, leukotrienes, cytokines, oxygen derived free radicals and plasma derived factors [67].

These chemical mediators can incite pain by directly stimulating the sensory nerves or causing vascular permeability which results in exudation and edema which in turn causes pain $[45,68]$.

\section{Treatment Of Interappointment Pain}

An integrated approach or the 3D approach has been put forth by Hargreaves and Seltzer for the management of interappointment pain where the condition is first diagnosed following which definitive treatment and drugs are prescribed. Clinical and radiographic examination of the area is initially carried out to diagnose the ailing tooth and the severity of pain after which definitive treatment is initiated. 


\section{Definitive treatment includes.}

\section{Reinstrumentation}

The symptomatic tooth is re entered, patency obtained and chemomechanical preparation is repeated with copious irrigation so that the leftover infected tissue, microorganisms, bacterial toxins and the inflammatory exudates are flushed out thereby relieving the localised tissue pressure in the periapical area [11].

\section{Cortical Trephination; Incision and Drainage}

These are invasive treatment protocols that are carried out in case the patient presents with swelling. These techniques immediately relieve the pressure exerted by inflammatory exudates or abscess over the periapical tissues and relieve interappointment pain [69, 70].

\section{Intracanal Medicaments}

Intracanal medicaments are commonly placed in the root canal during the interappointment period to control interappointment pain. Placement of medicaments would disinfect the root canal and relieve the inflammation thereby preventing the collection of exudates and compression of the periapical tissues. Several studies have been conducted where apart from calcium hydroxide, corticosteroids have also been proven effective for canal disinfection and relieving interappointment pain [71-73].

\section{Occlusal Reduction}

This is an invasive but effective technique for the management of interappointment pain [74]. Occlusal reduction would relieve the tooth from contacting the opposing tooth which would reduce the stimulation of periapical nociceptors and there by alleviates pain.

\section{Drugs}

The drugs commonly used to control interappointment pain are antibiotics and analgesics.

Antibiotics: Antibiotics were earlier prescribed frequently to patients undergoing endodontic treatment as a prophylactic measure to avoid interappointment pain. These drugs were prescribed as first line drugs to patients reporting with interappointment pain during endodontic treatment $[75,76]$. With the upsurge of bacterial resistance due to widespread antibiotic use, it was indicated to use these drugs only if systemic manifestation of infection was evident [77].

Non Steroidal Anti Inflammatory Drugs (NSAIDs): These are commonly employed drugs for the management of interappointment pain in endodontics. NSAIDs act both centrally and peripherally by inhibiting the cyclooxygenase pathway there by inhibiting the release of mediators of inflammation $[78,79]$.

So far, oral route has been most widely used for administration of analgesics to manage endodontic pain. Infrequently used routes of administration of analgesics include intramuscular and submucosal drug delivery.
Frequent use of analgesics resulted in severe gastrointestinal side effects and this led researchers to look for an alternate drug or route of delivery [80]. In the mid 1900s, some researchers proposed the use of intracanal route of delivery of analgesics and corticosteroids after chemo mechanical preparation of the root canal and noticed significant reduction in interappointment pain of root canal treatment $[10,72,81]$.

Intra canal drug delivery can therefore be developed as a novel technique for local drug administration to control interappointment pain. In the root canal, the pain site is very specific and the surface area is small which makes it possible for target oriented drug delivery. Also, the concentration of the analgesic required to attain analgesia is less when compared to the dosage required for systemic administration $[80,82]$. With the local administration of the analgesic, the first pass metabolism is bypassed and the analgesic is deposited directly at the site of its action. Hence, intracanal administration of analgesics would.

- Reduce the side effects due to systemic use.

- Reduce the dosage of the drug required to achieve analgesia.

- Speed up the analgesic action of the drug.

- If effective, would eliminate the necessity of post procedural analgesic medication in any other form.

Our institution is passionate about high quality evidence based research and has excelled in various fields [42, 83-92].

The studies conducted in the past with intracanal administration of analgesics have used the drug in the form of a paste, moreover the dosages of the drug are not standardized and ready made formulations prepared for systemic use have been utilized. Further studies can be conducted with analgesic solutions that would easily percolate into the periapical area to control periapical inflammation. Also, standardization of drugs have to be carried out and preparations with plasma concentrations of the drugs can be formulated to check the effectiveness to control endodontic pain.

\section{Conclusion}

The causes of interappointment pain can be microbial, chemical or physical factors which irritate the periapical tissues and induce inflammation which is manifested as pain. The most conservative management of inter appointment pain included intracanal delivery of analgesics which not only acts fast but also bypasses the systemic side effects.

There are no studies on intracanal analgesic delivery conducted systematically with proper study design or drug standardization. Future studies can focus on using lower concentrations and standardization of the drug to assess effectiveness in the management of interappointment pain. Studies can also be designed to evaluate the effectiveness of intracanal analgesic in managing pain for both vital and nonvital teeth.

\section{References}

[1]. Morse DR, Koren LZ, Esposito JV, Goldberg JM, Belott RM, Sinai IH, et 
al. Asymptomatic teeth with necrotic pulps and associated periapical radiolucencies: relationship of flare-ups to endodontic instrumentation, antibiotic usage and stress in three separate practices at three different time periods. Int J Psychosom. 1986;33(1):5-87. Pubmed PMID: 3082783.

[2]. Torabinejad M, Cymerman JJ, Frankson M, Lemon RR, Maggio JD, Schilder $\mathrm{H}$. Effectiveness of various medications on postoperative pain following complete instrumentation. J Endod. 1994 Jul;20(7):345-54. Pubmed PMID: 7996097.

[3]. Maddox DL, Walton RE, Davis CO. Incidence of posttreatment endodontic pain related to medicaments and other factors. J Endod. 1977 Dec;3(12):447-57. Pubmed PMID: 27529893.

[4]. SELTZER S, BENDER IB, EHRENREICH J. Incidence and duration of pain following endodontic therapy. Relationship to treatment with sulfonamides and to other factors. Oral Surg Oral Med Oral Pathol. 1961 Jan;14:74-82. Pubmed PMID: 13749944.

[5]. Kleier DJ, Mullaney TP. Effects of formocresol on posttreatment pain of endodontic origin in vital molars. J Endod. 1980 May;6(5):566-9. Pubmed PMID: 7005374.

[6]. Clem WH. Posttreatment endodontic pain. J Am Dent Assoc. 1970 Nov;81(5):1166-70. Pubmed PMID: 5272982.

[7]. Ehrmann EH. Endodontology - Biologic Considerations in Endodontic Procedures: S. Seltzer, Australian Endodontic Newsletter. 2010;p. 14-5.

[8]. Fox J, Atkinson JS, Dinin AP, Greenfield E, Hechtman E, Reeman CA, et al. Incidence of pain following one-visit endodontic treatment. Oral Surg Oral Med Oral Pathol. 1970 Jul;30(1):123-30. Pubmed PMID: 5269799.

[9]. Harrison JW, Gaumgartner JC, Svec TA. Incidence of pain associated with clinical factors during and after root canal therapy. Part 1. Interappointment pain. J Endod. 1983 Sep;9(9):384-7. Pubmed PMID: 6579198.

[10]. Moskow A, Morse DR, Krasner P, Furst ML. Intracanal use of a corticosteroid solution as an endodontic anodyne. Oral Surg Oral Med Oral Pathol. 1984 Nov;58(5):600-4. Pubmed PMID: 6595622.

[11]. Siqueira Jr JF, Barnett FJ. Interappointment pain: mechanisms, diagnosis, and treatment. Endodontic Topics. 2004 Mar;7(1):93-109.

[12]. Govindaraju L, Gurunathan D. Effectiveness of Chewable Tooth Brush in Children-A Prospective Clinical Study. J Clin Diagn Res. 2017 Mar;11(3):ZC31-ZC34. Pubmed PMID: 28511505.

[13]. Christabel A, Anantanarayanan P, Subash P, Soh CL, Ramanathan M, Muthusekhar MR, et al. Comparison of pterygomaxillary dysjunction with tuberosity separation in isolated Le Fort I osteotomies: a prospective, multi-centre, triple-blind, randomized controlled trial. Int J Oral Maxillofac Surg. 2016 Feb;45(2):180-5. Pubmed PMID: 26338075.

[14]. Soh CL, Narayanan V. Quality of life assessment in patients with dentofacial deformity undergoing orthognathic surgery--a systematic review. Int J Oral Maxillofac Surg. 2013 Aug;42(8):974-80. Pubmed PMID: 23702370.

[15]. Mehta M, Deeksha, Tewari D, Gupta G, Awasthi R, Singh H, et al. Oligonucleotide therapy: An emerging focus area for drug delivery in chronic inflammatory respiratory diseases. Chem Biol Interact. 2019 Aug 1;308:206215. Pubmed PMID: 31136735.

[16]. Ezhilarasan D, Apoorva VS, Ashok Vardhan N. Syzygium cumini extract induced reactive oxygen species-mediated apoptosis in human oral squamous carcinoma cells. J Oral Pathol Med. 2019 Feb;48(2):115-121. Pubmed PMID: 30451321.

[17]. Campeau PM, Kasperaviciute D, Lu JT, Burrage LC, Kim C, Hori M, et al. The genetic basis of DOORS syndrome: an exome-sequencing study. Lancet Neurol. 2014 Jan;13(1):44-58. Pubmed PMID: 24291220.

[18]. Sneha S. Knowledge and awareness regarding antibiotic prophylaxis for infective endocarditis among undergraduate dental students. Asian Journal of Pharmaceutical and Clinical Research. 2016 Oct 1:154-9.

[19]. Christabel SL, Gurunathan D. Prevalence of type of frenal attachment and morphology of frenum in children, Chennai, Tamil Nadu. World J Dent. 2015 Oct;6(4):203-7.

[20]. Kumar S, Rahman RE. Knowledge, awareness, and practices regarding biomedical waste management among undergraduate dental students. Asian Journal of Pharmaceutical and Clinical Research. 2017;10(8):341

[21]. Sridharan G, Ramani P, Patankar S. Serum metabolomics in oral leukoplakia and oral squamous cell carcinoma. J Cancer Res Ther. 2017 JulSep;13(3):556-561. Pubmed PMID: 28862226.

[22]. Ramesh A, Varghese SS, Doraiswamy JN, Malaiappan S. Herbs as an antioxidant arsenal for periodontal diseases. J Intercult Ethnopharmacol. 2016 Jan 27;5(1):92-6. Pubmed PMID: 27069730.

[23]. Thamaraiselvan M, Elavarasu S, Thangakumaran S, Gadagi JS, Arthie T. Comparative clinical evaluation of coronally advanced flap with or without platelet rich fibrin membrane in the treatment of isolated gingival recession. J Indian Soc Periodontol. 2015 Jan-Feb;19(1):66-71. Pubmed PMID: 25810596

[24]. Thangaraj SV, Shyamsundar V, Krishnamurthy A, Ramani P, Ganesan K, Muthuswami M, et al. Molecular Portrait of Oral Tongue Squamous Cell
Carcinoma Shown by Integrative Meta-Analysis of Expression Profiles with Validations. PLoS One. 2016 Jun 9;11(6):e0156582. Pubmed PMID: 27280700.

[25]. Ponnulakshmi R, Shyamaladevi B, Vijayalakshmi P, Selvaraj J. In silico and in vivo analysis to identify the antidiabetic activity of beta sitosterol in adipose tissue of high fat diet and sucrose induced type-2 diabetic experimental rats. Toxicol Mech Methods. 2019 May;29(4):276-290. Pubmed PMID: 30461321.

[26]. Ramakrishnan M, Bhurki M. Fluoride, Fluoridated Toothpaste Efficacy And Its Safety In Children-Review. International Journal of Pharmaceutical Research. 2018 Oct 1;10(04):109-14.

[27]. Govindaraju L, Gurunathan D. Effectiveness of Chewable Tooth Brush in Children-A Prospective Clinical Study. J Clin Diagn Res. 2017 Mar;11(3):ZC31-ZC34. Pubmed PMID: 28511505.

[28]. Christabel A, Anantanarayanan P, Subash P, Soh CL, Ramanathan M, Muthusekhar MR, et al. Comparison of pterygomaxillary dysjunction with tuberosity separation in isolated Le Fort I osteotomies: a prospective, multi-centre, triple-blind, randomized controlled trial. Int J Oral Maxillofac Surg. 2016 Feb;45(2):180-5. Pubmed PMID: 26338075.

[29]. Soh CL, Narayanan V. Quality of life assessment in patients with dentofacial deformity undergoing orthognathic surgery--a systematic review. Int J Oral Maxillofac Surg. 2013 Aug;42(8):974-80. Pubmed PMID: 23702370.

[30]. Mehta M, Deeksha, Tewari D, Gupta G, Awasthi R, Singh H, et al. Oligonucleotide therapy: An emerging focus area for drug delivery in chronic inflammatory respiratory diseases. Chem Biol Interact. 2019 Aug 1;308:206215. Pubmed PMID: 31136735.

[31]. Ezhilarasan D, Apoorva VS, Ashok Vardhan N. Syzygium cumini extract induced reactive oxygen species-mediated apoptosis in human oral squamous carcinoma cells. J Oral Pathol Med. 2019 Feb;48(2):115-121. Pubmed PMID: 30451321

[32]. Campeau PM, Kasperaviciute D, Lu JT, Burrage LC, Kim C, Hori M, et al. The genetic basis of DOORS syndrome: an exome-sequencing study. Lancet Neurol. 2014 Jan;13(1):44-58. Pubmed PMID: 24291220.

[33]. Sneha S. Knowledge and awareness regarding antibiotic prophylaxis for infective endocarditis among undergraduate dental students. Asian Journal of Pharmaceutical and Clinical Research. 2016 Oct 1:154-9.

[34]. Christabel SL, Gurunathan D. Prevalence of type of frenal attachment and morphology of frenum in children, Chennai, Tamil Nadu. World J Dent. 2015 Oct;6(4):203-7.

[35]. Kumar S, Rahman RE. Knowledge, awareness, and practices regarding biomedical waste management among undergraduate dental students. Asian Journal of Pharmaceutical and Clinical Research. 2017;10(8):341.

[36]. Sridharan G, Ramani P, Patankar S. Serum metabolomics in oral leukoplakia and oral squamous cell carcinoma. J Cancer Res Ther. 2017 JulSep;13(3):556-561. Pubmed PMID: 28862226

[37]. Ramesh A, Varghese SS, Doraiswamy JN, Malaiappan S. Herbs as an antioxidant arsenal for periodontal diseases. J Intercult Ethnopharmacol. 2016 Jan 27;5(1):92-6. Pubmed PMID: 27069730.

[38]. Thamaraiselvan M, Elavarasu S, Thangakumaran S, Gadagi JS, Arthie T. Comparative clinical evaluation of coronally advanced flap with or without platelet rich fibrin membrane in the treatment of isolated gingival recession. J Indian Soc Periodontol. 2015 Jan-Feb;19(1):66-71. Pubmed PMID: 25810596.

[39]. Thangaraj SV, Shyamsundar V, Krishnamurthy A, Ramani P, Ganesan K, Muthuswami M, et al. Molecular Portrait of Oral Tongue Squamous Cell Carcinoma Shown by Integrative Meta-Analysis of Expression Profiles with Validations. PLoS One. 2016 Jun 9;11(6):e0156582. Pubmed PMID: 27280700.

[40]. Ponnulakshmi R, Shyamaladevi B, Vijayalakshmi P, Selvaraj J. In silico and in vivo analysis to identify the antidiabetic activity of beta sitosterol in adipose tissue of high fat diet and sucrose induced type- 2 diabetic experimental rats. Toxicol Mech Methods. 2019 May;29(4):276-290. Pubmed PMID 30461321.

[41]. Ramakrishnan M, Bhurki M. Fluoride, Fluoridated Toothpaste Efficacy And Its Safety In Children-Review. International Journal of Pharmaceutical Research. 2018 Oct 1;10(04):109-14.

[42]. Ezhilarasan D, Apoorva VS, Ashok Vardhan N. Syzygium cumini extract induced reactive oxygen species-mediated apoptosis in human oral squamous carcinoma cells. J Oral Pathol Med. 2019 Feb;48(2):115-121. Pubmed PMID: 30451321.

[43]. Torabinejad M, Kettering JD, McGraw JC, Cummings RR, Dwyer TG, Tobias TS. Factors associated with endodontic interappointment emergencies of teeth with necrotic pulps. J Endod. 1988 May;14(5):261-6. Pubmed PMID: 3251982

[44]. Seltzer S, Naidorf IJ. Flare-ups in endodontics: I. Etiological factors. Journal of Endodontics. 1985 Nov 1;11(11):472-8.

[45]. Trowbridge HO, Emling RC, Fornatora M. Inflammation. A review of the 
process. Implant Dentistry. 1997 Oct 1;6(3):238.

[46]. Bartels HA, Naidorf IJ, Blechman H. A study of some factors associated with endodontic "flare-ups". Oral Surgery, Oral Medicine, Oral Pathology. 1968 Feb 1;25(2):255-61.

[47]. Walton R, Fouad A. Endodontic interappointment flare-ups: a prospective study of incidence and related factors. J Endod. 1992 Apr;18(4):172-7. Pubmed PMID: 1402571.

[48]. Walton RE. Interappointment flare-ups: incidence, related factors, prevention, and management. Endodontic Topics. 2002 Nov;3(1):67-76.

[49]. Versiani MA, Basrani B, Sousa-Neto MD, editors. The root canal anatomy in permanent dentition. Springer; 2018 Jul 25.

[50]. Sundqvist GK, Eckerbom MI, Larsson AP, Sjögren UT. Capacity of anaerobic bacteria from necrotic dental pulps to induce purulent infections. Infect Immun. 1979 Aug;25(2):685-93. Pubmed PMID: 489126

[51]. Baumgartner JC, Falkler WA Jr, Beckerman T. Experimentally induced infection by oral anaerobic microorganisms in a mouse model. Oral Microbiol Immunol. 1992 Aug;7(4):253-6. Pubmed PMID: 1408362.

[52]. Kesavalu L, Holt SC, Ebersole JL. Virulence of a polymicrobic complex, Treponema denticola and Porphyromonas gingivalis, in a murine model. Oral Microbiol Immunol. 1998 Dec;13(6):373-7. Pubmed PMID: 9872114 .

[53]. Siqueira JF Jr, Magalhães FA, Lima KC, de Uzeda M. Pathogenicity of facultative and obligate anaerobic bacteria in monoculture and combined with either Prevotella intermedia or Prevotella nigrescens. Oral Microbiol Immunol. 1998 Dec;13(6):368-72. Pubmed PMID: 9872113.

[54]. Yoneda M, Hirofuji T, Anan H, Matsumoto A, Hamachi T, Nakayama K, et al. Mixed infection of Porphyromonas gingivalis and Bacteroides forsythus in a murine abscess model: involvement of gingipains in a synergistic effect. J Periodontal Res. 2001 Aug;36(4):237-43. Pubmed PMID: 11519697.

[55]. Siqueira JF Jr. Endodontic infections: concepts, paradigms, and perspectives. Oral Surg Oral Med Oral Pathol Oral Radiol Endod. 2002 Sep;94(3):28193. Pubmed PMID: 12324780

[56]. Mims CA, Nash AA, Stephen J. Mims' pathogenesis of infectious disease. Gulf Professional Publishing: 2001.

[57]. Finlay BB, Falkow S. Common themes in microbial pathogenicity revisited. Microbiol Mol Biol Rev. 1997 Jun;61(2):136-69. Pubmed PMID: 9184008.

[58]. Siqueira JF Jr. Microbial causes of endodontic flare-ups. Int Endod J. 2003 Jul;36(7):453-63. Pubmed PMID: 12823700.

[59]. Wittgow WC Jr, Sabiston CB Jr. Microorganisms from pulpal chambers of intact teeth with necrotic pulps. J Endod. 1975 May;1(5):168-71. Pubmed PMID: 1061795

[60]. Sundqvist G. Ecology of the root canal flora. J Endod. 1992 Sep;18(9):42730. Pubmed PMID: 9796509.

[61]. Siqueira JF Jr, Lima KC. Staphylococcus epidermidis and Staphylococcus xylosus in a secondary root canal infection with persistent symptoms: a case report. Aust Endod J. 2002 Aug;28(2):61-3. Pubmed PMID: 12360671

[62]. Sabala CL, Powell SE. Sodium hypochlorite injection into periapical tissues. J Endod. 1989 Oct;15(10):490-2. Pubmed PMID: 2639943.

[63]. Becker GL, Cohen S, Borer R. The sequelae of accidentally injecting sodium hypochlorite beyond the root apex. Report of a case. Oral Surg Oral Med Oral Pathol. 1974 Oct;38(4):633-8. Pubmed PMID: 4547330.

[64]. Mehra P, Clancy C, Wu J. Formation of a facial hematoma during endodontic therapy. J Am Dent Assoc. 2000 Jan;131(1):67-71. Pubmed PMID: 10649874

[65]. Hales JJ, Jackson CR, Everett AP, Moore SH. Treatment protocol for the management of a sodium hypochlorite accident during endodontic therapy. Gen Dent. 2001 May-Jun;49(3):278-81. Pubmed PMID: 12004727.

[66]. Lindgren P, Eriksson KF, Ringberg A. Severe facial ischemia after endodontic treatment. J Oral Maxillofac Surg. 2002 May;60(5):576-9. Pubmed PMID: 11988940.

[67]. Cotran RS, Kumar V, Robbins SL. Pathologic basis of disease Philadelphia. Pa: Saunders. 1994:51-92.

[68]. Ryan GB, Majno G. Acute inflammation. A review. Am J Pathol. 1977 Jan;86(1):183-276. Pubmed PMID: 64118

[69]. Chestner SB, Selman AJ, Friedman J, Heyman RA. Apical fenestration: solution to recalcitrant pain in root canal therapy. J Am Dent Assoc. 1968 Oct;77(4):846-8. Pubmed PMID: 5244496.

[70]. Houck V, Reader A, Beck M, Nist R, Weaver J. Effect of trephination on postoperative pain and swelling in symptomatic necrotic teeth. Oral Surg Oral Med Oral Pathol Oral Radiol Endod. 2000 Oct;90(4):507-13. Pubmed PMID: 11027389

[71]. Kim D, Kim E. Antimicrobial effect of calcium hydroxide as an intracanal medicament in root canal treatment: a literature review - Part II. in vivo studies. Restor Dent Endod. 2015 May;40(2):97-103. Pubmed PMID: 25984470.

[72]. Rogers MJ, Johnson BR, Remeikis NA, BeGole EA. Comparison of effect of intracanal use of ketorolac tromethamine and dexamethasone with oral ibu- profen on post treatment endodontic pain. J Endod. 1999 May;25(5):381-4. Pubmed PMID: 10530266.

[73]. Negm MM. Intracanal use of a corticosteroid-antibiotic compound for the management of posttreatment endodontic pain. Oral Surg Oral Med Oral Pathol Oral Radiol Endod. 2001 Oct;92(4):435-9. Pubmed PMID: 11598580.

[74]. Rosenberg PA, Babick PJ, Schertzer L, Leung A. The effect of occlusal reduction on pain after endodontic instrumentation. J Endod. 1998 Jul;24(7):4926. Pubmed PMID: 9693578.

[75]. Whitten BH, Gardiner DL, Jeansonne BG, Lemon RR. Current trends in endodontic treatment: report of a national survey. J Am Dent Assoc. 1996 Sep;127(9):1333-41. Pubmed PMID: 8854609.

[76]. Yingling NM, Byrne BE, Hartwell GR. Antibiotic use by members of the American Association of Endodontists in the year 2000: report of a national survey. J Endod. 2002 May;28(5):396-404. Pubmed PMID: 12026927.

[77]. Fouad AF. Are antibiotics effective for endodontic pain? An evidence-based review. Endodontic Topics. 2002 Nov;3(1):52-66.

[78]. Hargreaves KM, Keiser K. Development of new pain management strategies. J Dent Educ. 2002 Jan;66(1):113-21. Pubmed PMID: 12358098.

[79]. Keiser K, Hargreaves KM. Building effective strategies for the management of endodontic pain. Endodontic Topics. 2002 Nov;3(1):93-105.

[80]. Stockman A, Varigos GA, Muirden KD. Comparison of effectiveness of mefenamic acid and ibuprofen in treatment of rheumatoid arthritis. Med J Aust. 1976 Nov 27;2(22):819-21. Pubmed PMID: 796645.

[81]. WOLFSOHN BL. The role of hydrocortisone in the control of apical periodontitis. Oral Surg Oral Med Oral Pathol. 1954 Mar;7(3):314-21. Pubmed PMID: 13145202.

[82]. Roy S. A double-blind comparison of a propionic acid derivative (ibuprofen) and a fenamate (mefenamic acid) in the treatment of dysmenorrhea. Obstet Gynecol. 1983 May;61(5):628-32. Pubmed PMID: 6835617.

[83]. Vijayashree Priyadharsini J. In silico validation of the non-antibiotic drugs acetaminophen and ibuprofen as antibacterial agents against red complex pathogens. J Periodontol. 2019 Dec;90(12):1441-1448. Pubmed PMID: 31257588.

[84]. J PC, Marimuthu T, C K, Devadoss P, Kumar SM. Prevalence and measurement of anterior loop of the mandibular canal using CBCT: A cross sectional study. Clin Implant Dent Relat Res. 2018 Aug;20(4):531-534. Pubmed PMID: 29624863.

[85]. Ramesh A, Varghese S, Jayakumar ND, Malaiappan S. Comparative estimation of sulfiredoxin levels between chronic periodontitis and healthy patients - A case-control study. J Periodontol. 2018 Oct;89(10):1241-1248. Pubmed PMID: 30044495

[86]. Ramadurai N, Gurunathan D, Samuel AV, Subramanian E, Rodrigues SJL. Effectiveness of 2\% Articaine as an anesthetic agent in children: randomized controlled trial. Clin Oral Investig. 2019 Sep;23(9):3543-3550. Pubmed PMID: 30552590

[87]. Sridharan G, Ramani P, Patankar S, Vijayaraghavan R. Evaluation of salivary metabolomics in oral leukoplakia and oral squamous cell carcinoma. J Oral Pathol Med. 2019 Apr;48(4):299-306. Pubmed PMID: 30714209.

[88]. Mathew MG, Samuel SR, Soni AJ, Roopa KB. Evaluation of adhesion of Streptococcus mutans, plaque accumulation on zirconia and stainless steel crowns, and surrounding gingival inflammation in primary molars: randomized controlled trial. Clin Oral Investig. 2020 Sep;24(9):3275-3280. Pubmed PMID: 31955271.

[89]. Samuel SR. Can 5-year-olds sensibly self-report the impact of developmental enamel defects on their quality of life? Int J Paediatr Dent. 2021 Mar;31(2):285-286. Pubmed PMID: 32416620.

[90]. R H, Ramani P, Ramanathan A, R JM, S G, Ramasubramanian A, et al. CYP2 C9 polymorphism among patients with oral squamous cell carcinoma and its role in altering the metabolism of benzo[a]pyrene. Oral Surg Oral Med Oral Pathol Oral Radiol. 2020 Sep;130(3):306-312. Pubmed PMID: 32773350.

[91]. Chandrasekar R, Chandrasekhar S, Sundari KKS, Ravi P. Development and validation of a formula for objective assessment of cervical vertebral bone age. Prog Orthod. 2020 Oct 12;21(1):38. Pubmed PMID: 33043408.

[92]. Vijayashree Priyadharsini J, Smiline Girija AS, Paramasivam A. In silico analysis of virulence genes in an emerging dental pathogen A. baumannii and related species. Arch Oral Biol. 2018 Oct;94:93-98. Pubmed PMID: 30015217. 